\title{
A Novel Sediment Transport Calculation Method-Based 3D CFD Model Investigation of a Critical Danube Reach
}

\author{
Gergely T. Török ${ }^{1,2 *}$, János Józsa ${ }^{1,2}$, Sándor Baranya ${ }^{2}$ \\ ${ }^{1}$ MTA-BME Water Management Research Group, Eötvös Lóránd Research Network, \\ Budapest University of Technology and Economics, Budapest, Hungary \\ ${ }^{2}$ Department of Hydraulics and Water Resources Engineering, Faculty of Civil Engineering, \\ Budapest University of Technology and Economics, Budapest, Hungary
}

Received: 31 May 2019

Accepted: 21 August 2019

\begin{abstract}
Our paper presents an application case study of a recently published sediment transport calculation method. In the last few decades, important bed changes have taken place along a Danube section (rkm 1798 and rkm 1794), which caused primary problems, e.g., for navigation, flood risk management, and habitat-related processes. The earlier-presented studies highlighted the need for 3D CFD morphodynamic model investigation in order to estimate the expectable future changes. However, none of the sediment transport models in the literature are able to deal with the spatially and temporally varied dominant grain size in the bed load. For such a river section, a novel calculation method and its verification were presented in 2017, which is able to deal with such complexity. Therefore, the use of the novel method becomes justified. The model investigations result in important statements: the trendy bed level incision in the main channel is not expected anymore, but the formation of the new dynamic equilibrium state is presumable. Minor bed changes can take place in the groin fields and at the gravel bars in small time scale (e.g., during a flood wave), but no trendy erosion or sedimentation can be detected in the years scale.
\end{abstract}

Keywords: bed load calculation, 3D CFD model, sediment transport, mixed bed material, varied bed load, shear Reynolds number, Danube

\section{Introduction}

Many studies describe in detail that important bed changes were detectable in the river bed of the Upper Hungarian Danube in the last decades [1, 2].

*e-mail: torok.gergely@epito.bme.hu
The installation of the Gabcikovo hydropower plant in the upstream [3-5], other artificial interventions (e.g., groin fields, ripraps) and a significant volume of dredging $[1,6]$ upset the balance in the sediment and morphodynamic system. The altered morphodynamic processes led to remarkable bed changes [1, 6-8]. During 2-3 decades, bed incision to a few meters of magnitude was detected and ascertained as the main 
reason for the problems (e.g., in navigation, flood risk management, etc.) at the river section [4, 9]. Therefore, a particularly important question was to determine the expected bed change trends, and additionally, when the new dynamic equilibrium state would be formed.

Many previous studies have examined the problematic upper Hungarian Danube reach. The scientific investigations claimed consistently that the bed incision was still in progress in the 1990s and also in the early 2000s [3, 4, 7]. Since then, the not entirely satisfactory (in quality and also in quantity) measurement data hinder the researchers in conducting meaningful investigations regarding the ongoing trends. In turn, from the 2010s, the Department of Hydraulic and Water Resources Engineering of the Budapest University of Technology and Economics and the North-Transdanubian Water Directorate in Hungary elaborated increasingly target-orientated measurement campaigns at the river section between rkm 1798 and rkm 1794 (Fig. 1). The evaluated data brought important additional information, based on which the researchers could make approximate estimates regarding the localand reach-scale morphodynamic processes. The main outcomes were published in 2017 [2] as a) the studied river reach is close to a dynamic equilibrium state and b) the geometric alteration of the Vének upper and lower gravel bars (Fig. 1) are not expected in the year-scale, but slight abrasion accompanied by a minor bed level rise can appear. However, the paper emphasizes that additional studies are required for even more reliable morphodynamic investigation. The 3D computational modeling offers an alternative for analyzing and predicting the recent processes. That is, the numerical modeling-based investigation could be an important complementary manner with meaningful added value.

The continuous development of sediment transport calculation took place in recet decades [10-25]. In the 1950s, the applicability conditions of sediment transport calculation methods covered a narrow range of the morphodynamic conditions. For instance, those models could be used only for uniform bed material with steady flow conditions [18-20, 23]. Later, the improvement of the models led to the widening of the applicability limits [12, 15, 21, 22, 24]. Several studies introduce the applicability limits of the models, like the Sediment Engineering book, which provides an extensive summary of many formulas and their applicability conditions [10]. The most obvious limitation factors are the grain size (sand, or gravel) and the homogeneity of the bed content $[10,13,25,26]$. Besides those, bed slope [27], bed shear stress [28], the hydraulic flow regime $[10,20,29-31]$, and the measure of armoring [21, 22], etc. are also morphodynamic factors that determine the applicability and reliability of the sediment transport models.

In complex flow and morphological cases - e.g., situations where different morphodynamic processes like scouring, bed armoring and aggradation take place at the same time - a less limited sediment transport approximation method would be needed, particularly when sediment transport of varied (both in time and space) bed load composition occurs, e.g., in a nonuniform river bed with groin fields $[32,33]$. In such cases (a typical example is the presented Danube reach, where the typical $d_{50}$ varies between $0.1 \mathrm{~mm}$ and $25 \mathrm{~mm}$ [2]; Fig. 1), the applicability limits of the existing sediment transport formulas still set back the accuracy of the numerical modeling. Török et al. presented a novel calculation method [26] in 2017, which proved that the coupled application of different sediment transport methods can evidently increase the reliability of the bed change calculation. In that study, the van Rijn [19] and the Wilcock and Crowe [22] models were combined: the most accurate results could be arranged if the van Rijn model calculates the motion of the finer sediments and the transport of the coarser grains are estimated by the Wilcock and Crowe model.

The goal of this study is to involve the 3D CFD modeling tool in the morphological investigation of the presented critical Danube reach in order to

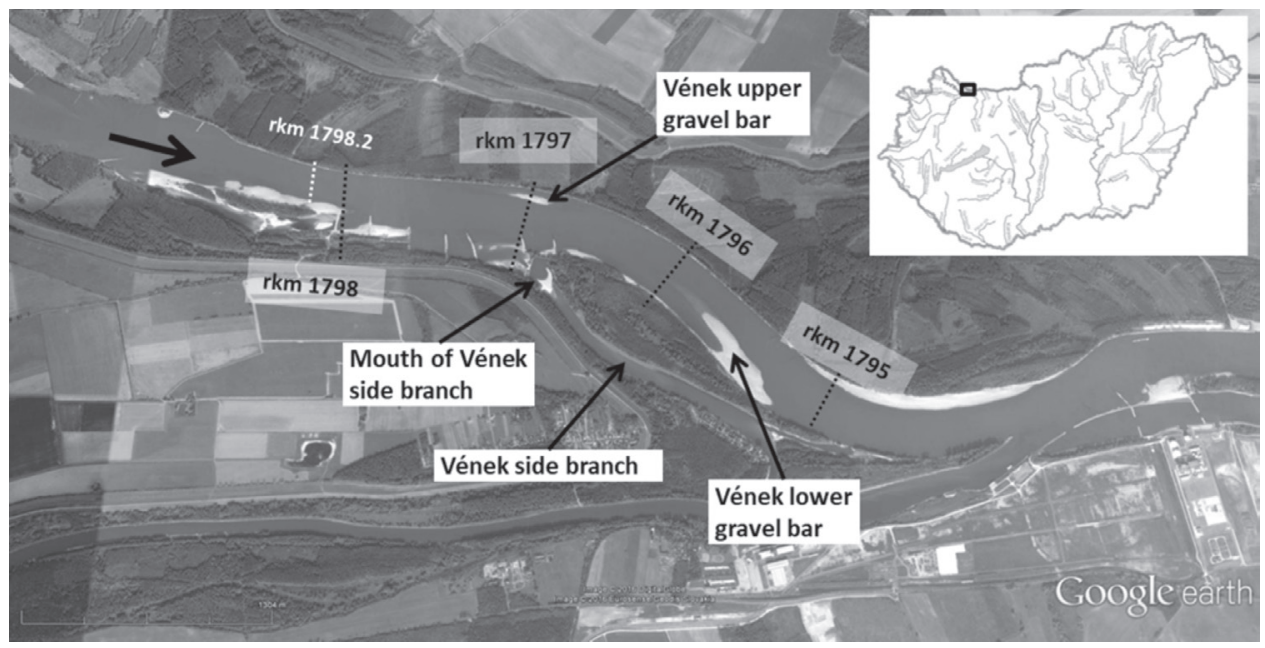

Fig. 1. Positions of the Vének upper and lower gravel bars and of the Vének side branch. 
supplement the earlier presented field measurementbased statements [2]. So, the interaction between the local phenomena and the reach-scale processes become examinable in more detail. For this reason, a 3D numerical model was applied involving the novel sediment transport calculation method [26].

\section{Numerical Methods}

\section{Flow Simulation}

In this study, the numerical model developed by Olsen was used $[34,35]$. The flow field is calculated based on the 3D Reynolds-averaged Navier-Stokes (RANS) equations, written as:

$$
\frac{\partial U_{i}}{\partial t}+U_{j} \frac{\partial U_{i}}{\partial x_{i}}=\frac{1}{\rho} \frac{\partial}{\partial x_{i}}\left(-P \delta_{i j}-\rho \overline{u_{\imath} u_{J}}\right)-F_{i},
$$

...where $U$ is the time $(t)$ averaged velocity, $x$ is the spatial geometrical scale, $\rho$ is water density, $P$ is the pressure, $\delta$ is the Kronecker delta and $u$ is the velocity fluctuation. In this equation, the first term on the left side is the transient term, the second is the convective term, while on the right side the pressure term, the Reynolds stress term, and the external forces term can be seen. The Reynolds stress term is calculated by the $k-\varepsilon$ turbulence closure [34, 36]. The model solves the equations by applying a finite-volume method and the SIMPLE algorithm [34, 36] on a 3D non-orthogonal, unstructured grid. Dirichlet boundary conditions have to be assigned at the inflow boundary [34]. At the outflow boundaries, zero-gradient conditions are used for all variables. As the boundary conditions for the RANS equations, at the inflow boundary the water discharges, at the outflow the water level was set. In the first cell, on the bed and sidewalls, the velocity profile is calculated from the well-known logarithmic formula [26] (bed roughness was computed as a function of the bed sediment distribution, according to the activated sediment transport formula).

The applied grid can be seen in Fig. 2, which also includes the floodplain area. If the flow discharge exceeds the bankfull discharge, the model is able to take into consideration the flush of the floodplain area. The study side was discretized with 355 cells in the streamwise direction and 150 cells in the lateral direction, respectively, yielding an average horizontal resolution of $10 \mathrm{~m}$ in the main channel, and $13 \mathrm{~m}$ in the floodplain area. Vertically, 11 layers were defined at every $10 \%$ of depth. The vegetation as a roughening impact can be taken into account as a sink term in the Navier-Stokes equations on the flood plain according to Fischer-Antze et al. [37]. The sink term is included in the external forces term $\left(F_{i}\right)$ in Eq. 1 and calculated as:

$$
F_{D, i}=\rho \frac{U_{i}}{2} C_{D} \lambda
$$

...where $F_{D, I}$ is the drag force on a vegetative element, $C_{D}$ is the drag coefficient of the vegetative element (the recommended value of 1.0 was applied) and $\lambda$ is the vegetative coefficient that actually indicates the diameter and the unit spatial density of the vegetative element $[37,38]$. The vegetation was defined based on a satellite image.

The herein applied 3D CFD model was already applied successfully for many sediment transport-related investigations [2, 25, 39-43] adapted and validated for the investigated Hungarian reach of the Danube, which was published in previous research works [40, 44]. Those studies have already demonstrated the reliable application of the 3D flow model.

\section{Sediment Transport Calculation}

The investigated reach has a meandering river pattern, whose shape naturally causes a spatially varied

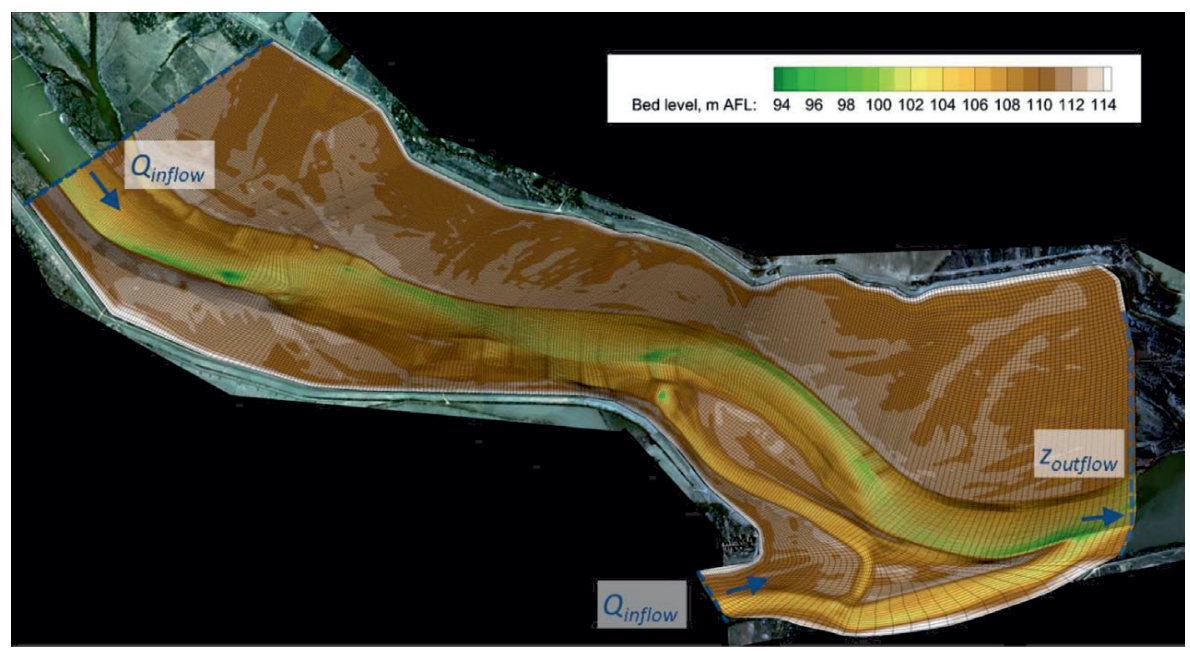

Fig. 2. Grid of the modeled Danube reach. 
flow field and bed material. Additionally, important river training measures increase the complexity of morphodynamic features. Consequently, a sediment transport calculation method was needed which is able to arrange both fine and coarse sediment transport. Thus, this study uses the sediment transport calculation method of Török et al. [26]. The base calculation principle is that the van Rijn model calculates the sediment transport in the cells of the grid, where sand domination is expected in the bed load. In the other part of the grid, the Wilcock and Crowe model is activated. The decision of the dominant sediment size in the bed load is determined according to Török et al. [45], which says that:

$$
\begin{gathered}
R e^{*}<\sim 300 \rightarrow \text { sand transport dominates } \\
\text { (van Rijn model activation), } \\
R e^{*}>\sim 400 \rightarrow \text { gravel transport dominates }
\end{gathered}
$$

(Wilcock and Crowe model activation),

...where $R e^{*}$ is shear Reynolds number [30, 45], calculated as:

$$
R e^{*}=\frac{u_{*} D}{v},
$$

...where $u_{*}$ is the shear velocity, $D$ is the grain diameter and $v$ is the kinematic viscosity of the fluid. $R e^{*}$ of 300-400 is considered a transition range, where the weighted form of the two transport models is used.

The detailed description and equations of the mentioned bed load transport formulas can be read in the Sedimentation Engineering book [10]. These models do not contain any variable to calibrate, the constants (the constant von Karman: $\kappa=0,41$, the lift coefficient: $\alpha_{L}=20$ ) and base equations (e.g., the original Shields curve was used in the van Rijn model $[20,46])$ as it is recommended. However, the two models calculate the bed roughness by two different ways: for the van Rijn model the recommended estimation method is:

$$
k_{s}=3 d_{90} \text {, }
$$

... while for the Wilcock and Crowe model it is:

$$
k_{s}=0,84 d_{90}
$$

Bed roughness was calculated accordingly: in the grid cells, where the van Rijn model was activated, the roughness was estimated by Eq. 4, otherwise by Eq. 5 .

In both cases, the formulas were complemented by the suspended sediment formula of van Rijn [46]. Thus, the bed load calculation was complemented with suspended load calculation by the van Rijn equation in each cell.

\section{Initial and Boundary Conditions}

The bed material parameterization was elaborated upon based on the field measurements introduced in Török and Baranya [2, 47], where 33 bed material samples were collected. The bed material could not be described with one value, because it is very varied spatially (typical $d_{50}$ varies between $0.1 \mathrm{~mm}$ and $25 \mathrm{~mm}$ [2]). The spatial $d_{50}$ distribution in the main channel was elaborated upon based on the idea presented in [48]. That is, in especially complex bed geometry a relationship between the calculated local bed shear stress value by $3 \mathrm{D}$ flow model at the mean-water level and the local $d_{50}$ can be stated. Accordingly, based on the fitted function, a transitional and continuous $d_{50}$ map can be estimated based on the calculated bed shear stress distribution. Thus, a linear equation of $d_{50}[\mathrm{~mm}]=1.06 * \tau+7.5$ (where $\tau$ is the bed shear stress, $\mathrm{N} / \mathrm{m}^{2}$ ) was fitted to the measured points.

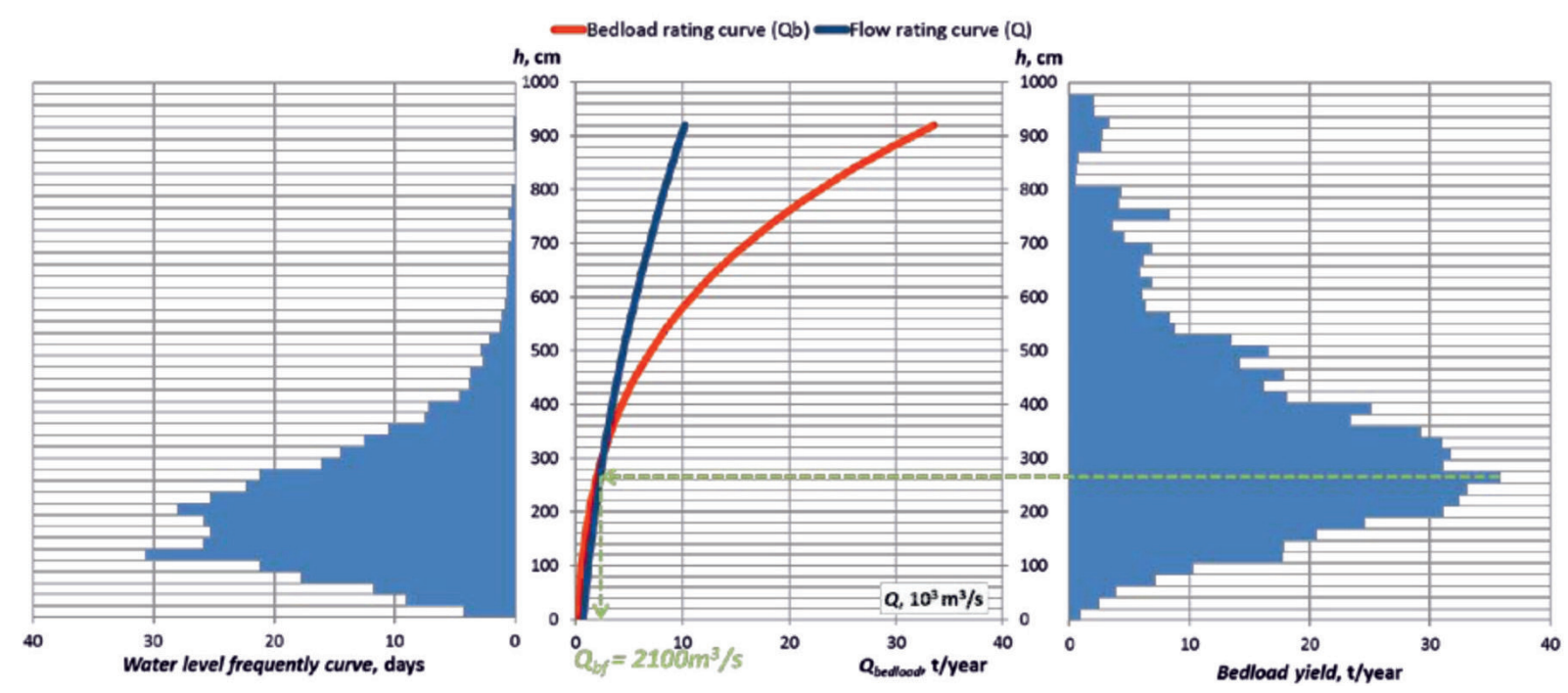

Fig. 3. Water level frequency curve, flow (1998-2016) and bed load (2010-2015) rating curves and the likely present yearly bed load amount as the function of the water level. 
Besides the main channel, the gravel bars and the finer sections (sand depositions and near-bank zones) were characterized with typical grain sizes, as other studies presented [49-51]. Thus, the average difference between the measured and estimated $d_{50}$ values was $3.2 \mathrm{~mm}$.

As to the floodplain bed material, there were no samples from there. Presumably, the bed material is coarse sand/fine gravel mixture, thus the $d_{50}$ was supposed to be $5 \mathrm{~mm}$ in the floodplain. Due to the lack of field data, the spatial distribution of the $d_{50}$ was assumed to be uniform.

The inflow suspended sediments and bed load was determined as the function of the flow discharge, according to measurement-based fitted curves presented in Török et al. and Ficsor [2, 52, 53]. Based on bed load sampling (2010-2015), the fitted bed load rating curve was calculated, which is illustrated by the red curve in Fig. 3 .

The bed changes during a 2-year-long period were investigated. In order to reduce the pre-calculated halfyear long duration of the simulation, only periods that exceed bed-forming flow discharge ([47] $Q>2100 \mathrm{~m}^{3} / \mathrm{s}$, Fig. 4) were simulated. The bed-forming discharge (also known as effective discharge [54]) is the flow rate that statistically transports the higher bed load rate considering the water level frequently. Multiplying the water level frequency curve (left Figure in Fig. 3) and bed load rating curve (blue curve in Fig. 3), the likely present yearly bed load amount as the function of the water level can be calculated. Finally, the maximum value of this diagram (right figure in Fig. 3) designates the water level at which the higher yearly sediment yield can be expected. The belonging water discharge (blue curve, middle figure in Fig. 3) is called the bedforming water discharge, which was calculated as $Q=2100 \mathrm{~m}^{3} / \mathrm{s}$ (Fig. 3).

Based on Fig. 3, 66\% of the annual bed load amount passed by the flow [47] above the bed-forming flow discharge. Therefore, the major bed changes are expected during these periods. Accordingly, the bed changes caused by eight flood waves were calculated, which means a total of 211 days (Fig. 4). Thus, the inflow boundary condition was the water discharge time series in Fig. 4, and the outflow boundary condition was given according to the belonging water level series (measurements by the North-Transdanubian Water Directorate). The flow discharge of the Mosoni-Danube is not registered daily. Therefore, the inlet water discharge of the tributary was set for a steady $40 \mathrm{~m}^{3} / \mathrm{s}$, which is the mean discharge of the Mosoni-Danube [55]. This steady discharge is $1.9 \%$ of the mean discharge of the Danube at the investigated section.

\section{Results and Discussion}

Based on the model results by the $R e^{*}$ dependent combining method, the morphological investigation of the Danube reach between $\sim$ rkm 1795 and rkm 1799 was performed. The core of the examination was to take advantage of the numerical modeling. Basically, two main questions were drawn up: what kind of local and reach-scale changes can be expected? That is, the present study does not focus on the bed change effect caused by given flood waves. The goal was to explore generalizable bed change trends linked to hydrological conditions.

As Liedermann et al. also presented [56], the flow discharge refers fairly well to the local sediment transport properties, such as the bed-load discharge. Based on this, a suggestion was stated that characteristic bed change maps can be calculated, which are able to indicate roughly the potential changes regarding different flow discharge ranges. The characteristic bed change maps were calculated for the flow discharge ranges of $2000-4000 \mathrm{~m}^{3} / \mathrm{s}, 4000-6000 \mathrm{~m}^{3} / \mathrm{s}$, $6000-8000 \mathrm{~m}^{3} / \mathrm{s}$ and for $8000-10000 \mathrm{~m}^{3} / \mathrm{s}$ [53]. [Characteristic water discharges are $Q_{m}=2000 \mathrm{~m}^{3} / \mathrm{s}$ (mean flow), $Q_{b f}=4300-4500 \mathrm{~m}^{3} / \mathrm{s}$ (range of bankfull discharge within the reach) $Q_{2}=5950 \mathrm{~m}^{3} / \mathrm{s}$, $Q_{10}=7950 \mathrm{~m}^{3} / \mathrm{s}$ and $Q_{100}=10400 \mathrm{~m}^{3} / \mathrm{s}$ (2-, $10-$ and 100 -year flood event) [55]. The daily bed change maps from the unsteady model results (including the rising and falling limbs of the eight flood waves) were sorted in the four discharge groups and then the average daily bed changes of the groups were calculated. Thus, the average daily bed change maps were created for the four discharge ranges (Fig. 5).

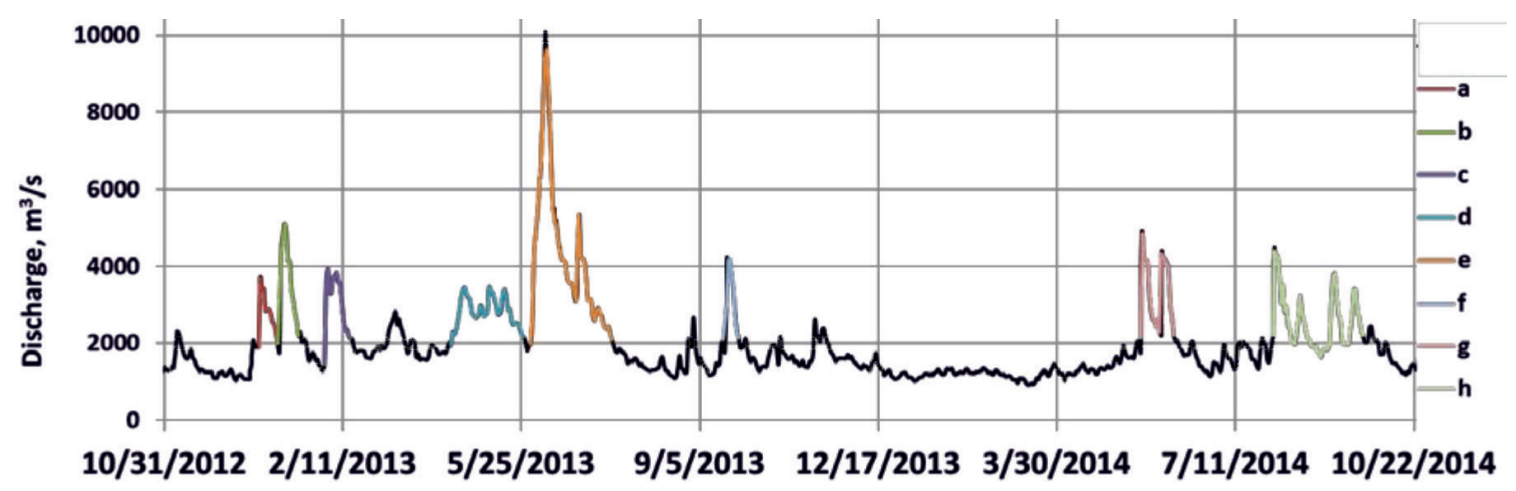

Fig. 4. Hydrograph at the inlet. 


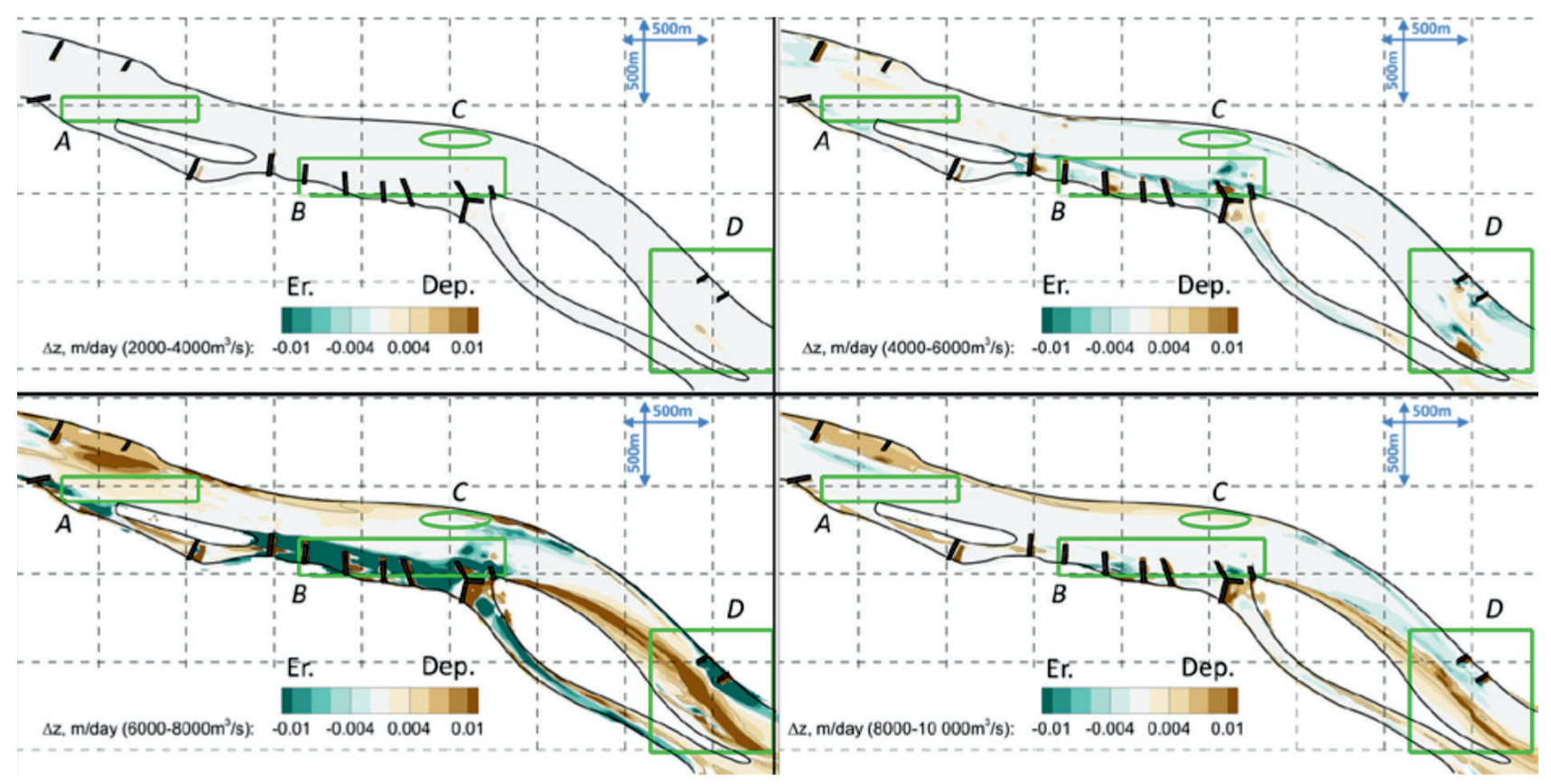

Fig. 5. Daily average bed change maps for discharge ranges of $2000-4000 \mathrm{~m}^{3} / \mathrm{s}, 4000-6000 \mathrm{~m}^{3} / \mathrm{s}, 6000-8000 \mathrm{~m}^{3} / \mathrm{s}$ and $8000-10000 \mathrm{~m}^{3} / \mathrm{s}$; the calculation was made from the bed change calculation for the eight flood waves.

The top left Figure shows the daily bed changes in the flow discharge range of $2000-4000 \mathrm{~m}^{3} / \mathrm{s}$. Almost the entire map is colored grey $(\Delta z< \pm 0.002 \mathrm{~m})$, which refers to a very stable bed surface. Despite the low daily change, long-lasting mean close discharge can presumably result in sedimentation in the groin fields (region $B$ ).

More significant erosion spots appear in the discharge range of $4000-6000 \mathrm{~m}^{3} / \mathrm{s}$. At this level, mainly scouring processes happen in the front of the groins (region $B$ ). However, it is also important that the erosion of the lower end of the Vének lower gravel bar (region $C$ ) can be detected. In addition, the eroded bed material of the gravel bar settled directly right after the erosion field, resulting in the downstream slight sliding of the bar.

The most important daily changes are expected in the discharge range of $6000-8000 \mathrm{~m}^{3} / \mathrm{s}$. It can be seen that considerable erosion takes place at the right bank groin field (region $B$ ) and at the surroundings of the left bank groin pair. At this discharge range, the flow rate exceeds the bankfull discharge range. This likely alters the recirculation flow field between the groins, resulting in higher velocities and erosion capacity. Important sediment deposition can be seen along the Vének lower gravel bar (region $C$ ). That is to say, the higher flood waves do not erode, but rather raise the Vének lower gravel bar. Also note that - as stated earlier - the sediment transport model usually underestimates the extent of the erosion and overestimates the deposition rates during the flood events [26]. Therefore, the width of the deposition is likely somewhat smaller and the extent of the erosion spot is larger. Overall, the sudden growth of the Vének lower gravel bar can be expected during higher water stages $\left(Q>4000 \mathrm{~m}^{3} / \mathrm{s}\right)$, while its sluggish wear happens below the bankfull discharge. Thus, this part of the bed geometry is an alternating part, where deposition and erosion follow each other. Therefore, no large time-scale alteration trend is expected. This statement agrees with the field-based measurement findings of Török and Baranya [2].

The daily bed changes map regarding the discharge range of $8000-10000 \mathrm{~m}^{3} / \mathrm{s}$ shows similar bed change nature, as the previous, but in a lower range. There are still detectable erosion spots at the groin fields (region $B$ ) but to a lesser extent. That is because the finer sediments were already transported by the lower discharges during the rising limb of the flood wave. This process explains why the rising limb of the flood waves transports the higher suspended sediment concentrations, rather than the falling limb [57]. The increasing of the Vének lower gravel bar (region $D$ ) is also visible.

At region $A$, no remarkable changes are calculated in either case. The Vének upper gravel bar stays stable in each discharge range, just like the white main stream almost everywhere. That is, the model results show that the Vének upper gravel bar and the bed level in the main stream in long time-scale seem to be in quasiequilibrium state. These results confirm statements based on field measurements of Török and Baranya [2]. Accordingly, the trendy bed level incision is no longer in progress, but the dynamic equilibrium state is formed.

The figures suggest the most important daily bed changes for the higher $\left(>6000 \mathrm{~m}^{3} / \mathrm{s}\right)$ flow discharge ranges. In turn, the water level frequency curve (Fig. 3) illustrates that the higher flood waves are more 
infrequent events, which draws attention to the emphatic role of the lower flow regimes in a long time-scale. This kind of phenomena is outlined in Fig. 3, where the determination of the bed-forming bed load discharge is illustrated. Even though the bed load discharge is much larger at higher flow discharges, the bed-forming discharge happens around the mean flow discharge.

In the case of the Vének lower gravel bar, its growth can be expected during the flood waves. It is also notable that the highest daily bed changes are predicted between $6000-8000 \mathrm{~m}^{3} / \mathrm{s}$, but not at the range of $8000-10000 \mathrm{~m}^{3} / \mathrm{s}$. A possible explanation is that the more easily moveable particles already get transported between $6000-8000 \mathrm{~m}^{3} / \mathrm{s}$ in the rising limb of a flood wave. Thus, by the time the discharge exceeds $8000 \mathrm{~m}^{3} / \mathrm{s}$, the bed surface becomes more resistant.

From the sediment transport aspect, bed shear stress is the most meaningful parameter of the flow. Therefore, it was examined in more detail. As presented by Liederman [56], the dependence of the bed shear stress on water flow discharges includes essential information with respect to the sediment transport and bed change processes. As the Du Boys equation [58] also suggests, increasing flow discharge results in bigger sediment transport capacity related to a channel section. However, the local connection between the flow discharge and bed shear stress can be more complicated, especially in the case of complex bed geometry. For this reason, the calculated bed shear stresses are depicted as the function of the flow discharges in Fig. 6. The markers belong to a given location illustrated in Fig. 6.

The deltoids represent the values from a point of a narrowed section. It can be seen that the bed shear stress increases with the flow discharge until the bankfull level. The very high stress values cause the armoring of the bed surface. In turn, between $Q_{b f}$ and $Q_{2}$, a significant $\sim 50 \%$ decrease of the bed shear stress happens, followed by a quasi-permanent phase. Despite the significant reduction of shear stress, the transport capacity is still high enough $\left(\sim 8 \mathrm{~N} / \mathrm{m}^{2}\right)$ to avoid sedimentation. The trend of shear stress can be explained by the displacement of the mainstream. During lower and mean water regimes, the main stream is cribbed in the deepest narrow part of the crosssection. However, the crescent water level causes the increase of the effective width of the flow. This process finally results in the displacement of the main stream. The corresponding cross-sectional bed shear stress distributions [2] can be seen in the left graph, where the values indicated by continuous curves were calculated from moving flow measurements by an acoustic Doppler current profiler (ADCP) regarding the peak of the historical flood wave in $2013\left(Q=10100 \mathrm{~m}^{3} / \mathrm{s}\right.$, black line) and a lower flow discharge $\left(Q=1500 \mathrm{~m}^{3} / \mathrm{s}\right.$, grey line) [2]. Both measurements were carried out by a WorkHorse Rio Grande $1200 \mathrm{kHz}$ instrument [59]. The bed shear stress values were estimated based on the LP method (logarithmic velocity profile method) [60-62] applying a $40 \mathrm{~m}$ wide moving average. The measured results also show how the bed shear stress in the narrowing sections takes a higher $\left(10-17 \mathrm{~N} / \mathrm{m}^{2}\right)$ value during a mean or lower flow condition than at around $Q_{100}$ discharge. That is how the measured and calculated results support each other. Furthermore, because the modeled period includes the measured historical flood wave in 2013 (Fig. 4), the calculated cross-sectional distribution was also indicated (regarding the peak of the flood wave) by the dotted curve. The root-meansquare deviation (RMSD) between the measured and calculated values was calculated for $2.17 \mathrm{~N} / \mathrm{m}^{2}$. Considering the inaccuracy of the ADCP measurements
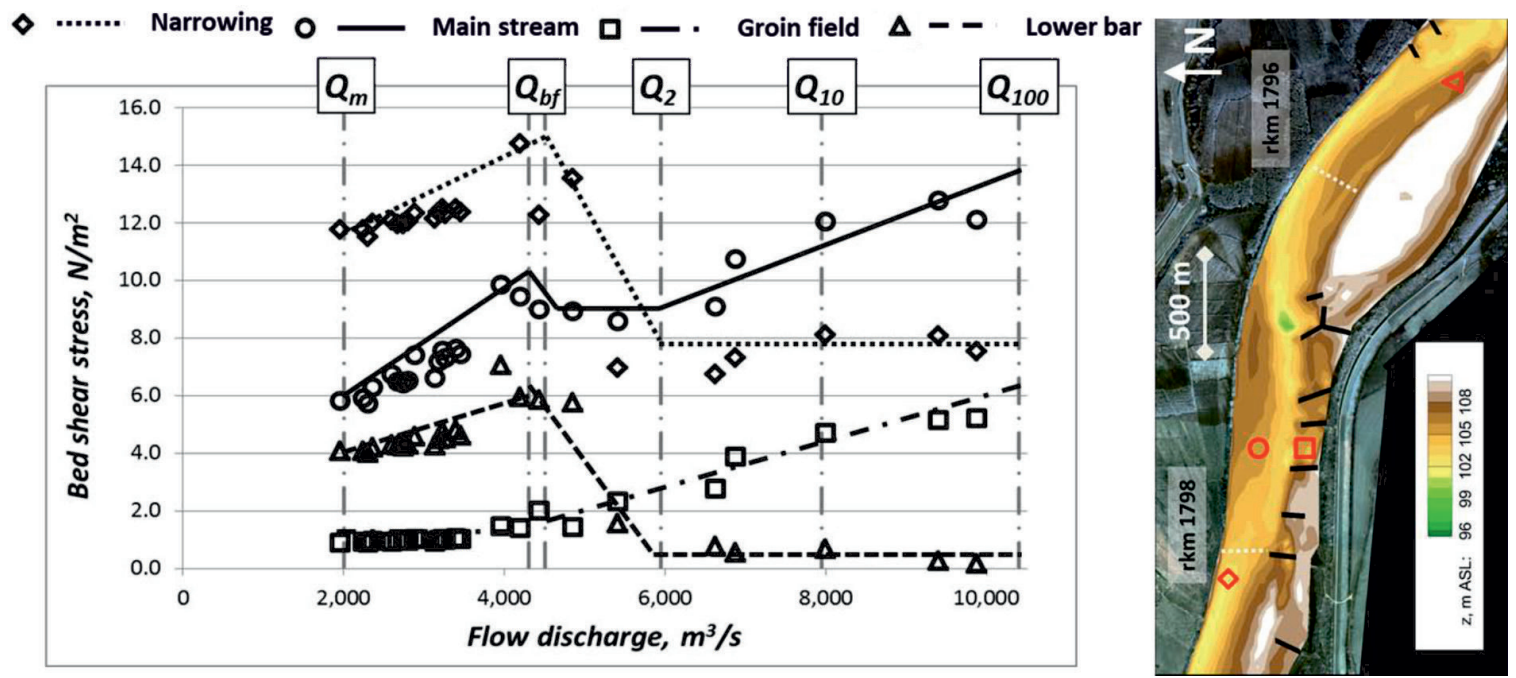

Fig. 6. Corresponding flow discharge and calculated bed shear stress values; characteristic water discharges are $Q_{m}=2000 \mathrm{~m}^{3} / \mathrm{s}(\mathrm{mean}$ flow), $Q_{b f}=4300-4500 \mathrm{~m}^{3} / \mathrm{s}$ (range of bankfull discharge within the reach), $Q_{2}=5950 \mathrm{~m}^{3} / \mathrm{s}, Q_{10}=7950 \mathrm{~m}^{3} / \mathrm{s}$ and $Q_{100}=10400 \mathrm{~m}^{3} / \mathrm{s}$ (2-, 10- and 100-year flood event) [55]; the right figure shows the locations of the points where the bed sheer stress-flow discharge connections are presented. 


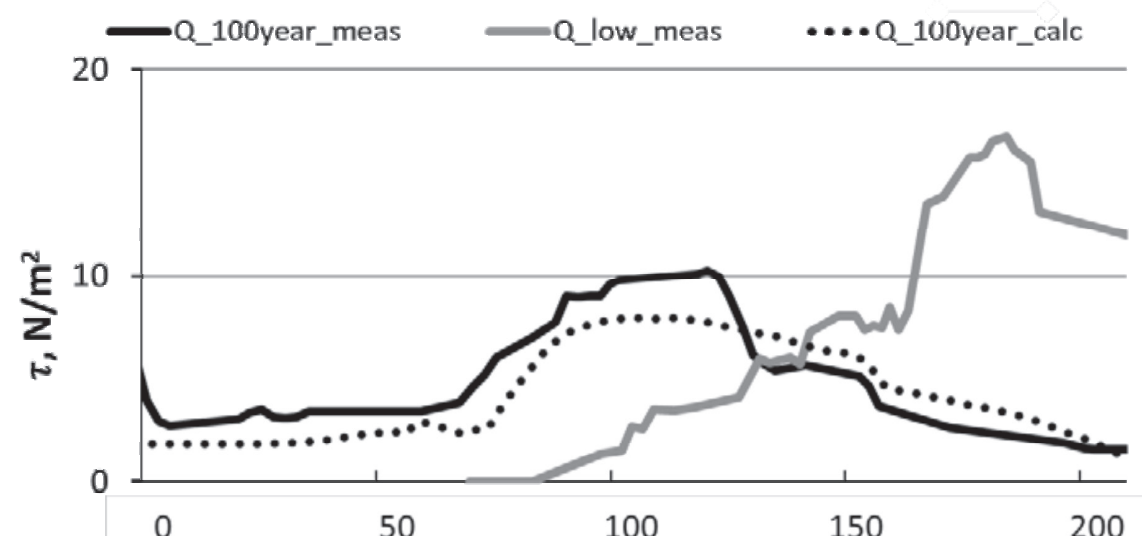

Fig. 7. Cross-sectional (rkm 1798.2, white dotted line in Fig. 1) bed shear stress distribution; the continuous and dotted black curves represent the measured and calculated values at the peak of a historical flood wave in $2013\left(Q_{-}\right.$100year $\left.=10100 \mathrm{~m}^{3} / \mathrm{s}\right)$; the grey curve shows the measured distribution at a lower flow condition $\left(Q \_l o w=1500 \mathrm{~m}^{3} / \mathrm{s}\right)[2]$.

and the LP estimation method [60,61], the results support the model validation and the statement that the model is able to estimate the morphodynamic variables (e.g., the bed shear stress) reliably for morphodynamic investigation purposes.

The trend of the bed shear values in the main channel (Fig. 6, circle) follows the nature that Liedermann [56] presented. That is, the bed shear stress increases until $Q_{b f}$. From that level, a quasi-invariant level comes. Finally, another rising section can be pointed out. In the same cross-section, a point in the groin field was also investigated. As the squares suggest, no remarkable alteration can be seen in the bed shear stress values until $Q_{b f}$. The magnitude of the values $\left(\sim 1 \mathrm{~N} / \mathrm{m}^{2}\right)$ explains the sedimentations at this river section during lower flows. In turn, the bed shear stress values show a clear growing trend above $Q_{b f}$, suggesting the flushing of the groin field.

Finally, the bed shear stresses at the lower end of the Vének lower bar were examined. Here, the points follow a very similar nature as the points in the narrowing did, but in a much lower range. Until $Q_{b f}$, the shear values happen between 4-6 N/m², causing both erosion and sedimentation. Both the $W \& C$ and the $v R$ models predict this shear stress range as critical for the grains with $4-8 \mathrm{~mm}$ diameters. That is, the selective erosion phenomenon occurs and results in the transport of the sand and the deposition of the gravel, forming the gravel bar. Above the $Q_{b f}$, the flow pattern changes and the bed shear stress falls off. This phenomenon causes the more important daily deposition of the fine fractions during flood waves (Fig. 5.).

Liedermann [56] mentions 0.004 average bed slope in their study, which is around the triple- quadruple of the average slope at the herein examined Hungarian Danube reach [2]. Accordingly, based on the Du Boys equation [58], the average bed shear stress is expected to be around half of the Austrian expected value. This is supported by the results of Liedermann and Fig. 6 . That is, the bed shear stresses over the flow discharge spectrum follow very similar trends, but the Hungarian values are half those of the Austrians.

Szilo and Bialik also studied the relationship between water discharge and sediment transport [63]. They investigated two creeks [64] and found that the bed load transport varies directly with the water discharge for lower water levels. This kind of connection is represented in the numerical model results, with the addition that the direct relationship seems to consist up to the bankfull discharge. Reaching the bankfull discharge, the local bed shear stress trends can be different in some locations of the river bed. This phenomenon can result in that for higher water levels, the connection of the water discharge-cross-sectional bed load rate is not unequivocal, which is in agreement with the observations of Szilo and Bialik [63]. They presented that the bed load transport-water discharge relationship can be described as both clockwise eight loop and also counter-clockwise eight loop.

As previously mentioned, the parameterization of the floodplain was elaborated upon based on approximation because there was no benchmark data (e.g., bed material sample, neither bed change map) either. Therefore, in order to examine the impact of the floodplain, the average bed shear stress values regarding the entire area covered by water, the area of the floodplain area covered by water and the main channel were calculated. The average values were calculated based on the corresponding area sizes, not on the number of calculation cells. The values are derived from the model run results regarding the historical flood wave (Fig. 4e).

Considering the average bed shear stress values regarding the main channel and the floodplain area separately, the $R^{2}$ values indicate linearly increasing natures (Fig. 8.). That is, the higher the flow discharge the bigger the average bed shear stress both on the floodplain area and also in the main channel. However, the " $X$ " markers indicate that the average bed shear stress of the floodplain increases more rapidly than the average shear stress in the main channel. A possible 


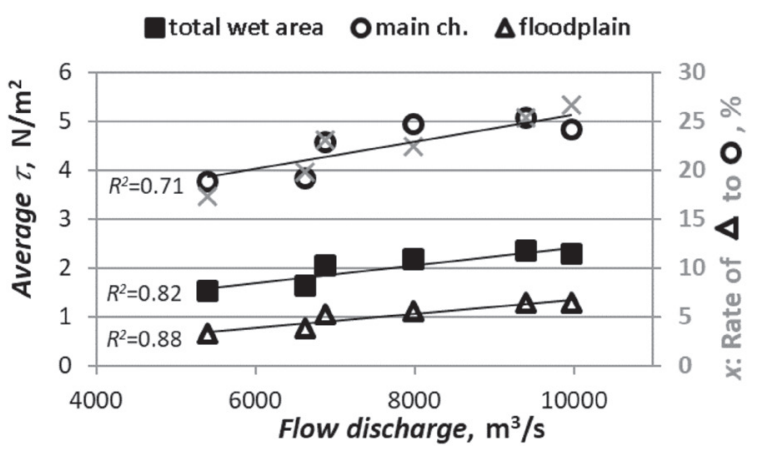

Fig. 8. Corresponding flow discharge and the areal average of the calculated bed shear stress values' in accordance with the legend, the average values belong to the entire area covered by water (square), the main channel (circle) and the are of the floodplain covered by water (triangle); for these data, the $R^{2}$ is also indicated; the " $\mathrm{X}$ " markers show the rate of the average bed shear stress on the floodplain to the average shear stress in the main channel.

reason for this kind of behavior is that the higher the flow discharge, the bigger the proportion of the water volume that is transported on the floodplain area.

It can also be seen that the average bed shear stress happens around $1 \mathrm{~N} / \mathrm{m}^{2}$ on the floodplain area, and $\sim 4-5 \mathrm{~N} / \mathrm{m}^{2}$ in the main channel. This suggests that the suspended sediment load dominates on the floodplain areas rather than the bed load transport. Thus, the accuracy and the reliability of the suspended sediment related measured data are the key factors for the estimation of the morphodynamic processes on the floodplain areas. Furthermore, the difference between the characteristics in sediment transport of the flood plain area and main channel highlights the need for the combined use of sediment transport models.

\section{Conclusions}

The advantages of numerical morphodynamic simulation-based investigation of problematic river reaches are known and evident. However, there are river reaches where the bed material and transported sediments can vary both in time and space between fine silt and coarse gravel, making it very difficult to choose a sediment transport model. For such complex cases, Török et al. presented a novel sediment transport calculation method in 2017. An application example of this calculation approach is presented in this study.

The model results show that the earlier changeable river section became more stable and the formation of a new dynamic equilibrium state is presumed. The main channel represents stable features, even during higher flood waves. The bed level can change in the groin fields and also at some parts of the gravel parts in shorter time-scale. However, even these parts of the river section display the formation of dynamic equilibrium state in longer, years-scale.
The results are consistent with the findings of previous field measurement-based papers, which highlights the reliability of the simulation results and also the effective application of the novel sediment transport calculation method of Török et al. Through this representative case study, local-scale spatiotemporal analysis of unique morphodynamic processes can be performed with the novel sediment transport modeling method, with complex flow and morphological features and non-uniform bed material composition. The developed numerical tool is a suitable investigation methodology for the analysis of future restoration measures as local- and reach-scale morphodynamic processes. Moreover, the interaction-mechanism between the two scales can be revealed.

In accordance with published field observations at other river sections, the numerical model showed that the local bed shear stress varies directly with the water discharge for lower water levels. However, the connection between the bed shear stress and water discharge is not unequivocal for higher flood waves. The herein presented results indicate that the direct connection is true in the whole channel up to the bankfull water discharge. As the local bed shear stress trends can be different for higher flood waves, the cross-sectional bed load discharge trend is nor trivial.

\section{Acknowledgement}

This research was supported by the Office for Research Groups Attached to Universities and Other Institutions (Eötvös Loránd Research Network) and SEDDON II cooperation programme Interreg V-A Austria-Hungary. Support of grant BME FIKP-VÍZ by EMMI (Ministry of Human Capacities) is also kindly acknowledged. The authors acknowledge the funding of the OTKA (Hungarian Scientific Research Fund) FK 128429 grant. The research was partly supported by the ÚNKP-19-4 New National Excellence Program of the Ministry for Innovation and Technology. The last author acknowledges the funding from the János Bolyai fellowship of the Hungarian Academy of Sciences.

\section{Conflict of Interest}

The authors declare no conflict of interest.

\section{References}

1. BARANYA S., JÓZSA J., TÖRÖK G.T., FICSOR J., MOHÁCSINÉ SIMON G., HABERSACK H., HAIMANN M., RIEGLER A., LIEDERMANN M., HENGL M. A Duna hordalékvizsgálatai a SEDDON osztrák-magyar együttmüködési projekt keretében (Introduction of the joint Austro-Hungarian sediment research under the SEDDON ERFE-project). Hidrológiai Közlöny, 95 (1), 41, 2015 [In Hungarian]. 
2. TÖRÖK G.T., BARANYA S. Morphological Investigation of a Critical Reach of the Upper Hungarian Danube. Periodica Polytechnica Civil Engineering, 61 (4), 752, 2017.

3. RÁKÓCZI L., SASS J. A Felső-Duna és a Szigetközi mellékágak mederalakulása a dunacsúni duzzasztómü üzembe helyezése után (Changes of the channel of the Hungarian Upper Danube and of the side river arms of the Szigetköz upon putting the Dunacsúny I. river barrage into operati. Vízügyi Közlemények, 77 (1), 46, 1995 [In Hungarian].

4. HOLUBOVÁ K., CAPEKOVÁ Z., SZOLGAY J. Impact of hydropower schemes at bedload regime and channel morphology of the Danube River. In River Flow 2004: Proceedings of the Second International Conference on Fluvial Hydraulics (pp. 135-142). Napoli: CRC Press. 2004.

5. FARKAS-IVÁNYI K., GUTI G. The Effect of Hydromorphological Changes on Habitat Composition of the Szigetköz Floodplain. ACTA ZOOLOGICA BULGARICA, 7, 117, 2014.

6. HABERSACK H., HAIMANN M., BARANYA S., JÓZSA J., RIEGLER A., SINDELAR C., LIEDERMANN M., FICSOR J., MOHÁCSINÉ SIMON G., HENGL M. Introduction of the joint Austro-Hungarian sediment research under the SEDDON ERFE-project. Österreichische Wasser- und Abfallwirtschaft, 66 (9-10), 340, 2014.

7. HOLUBOVÁ K., COMAJ M., LUKAC M., MRAVCOVÁ K., CAPEKOVÁ Z., ANTALOVÁ M. Final report in DuRe Flood project - 'Danube Floodplain Rehabilitation to Improve Flood Protection and Enhance the Ecological Values of the River in the Stretch between Sap and Szob. Bratislava. 2015.

8. VARGA-LEHOFER D.T. A felső-magyarországi Duna morfológiai változásainak elemzése (Investigation of the morphological changes of the Hungarian Upper Danube). BSc Thesis, manuscriprt: Budapest Univerity of Technology and Economics. 2014 [In Hungarian].

9. RÁKÓCZI L. A Duna Szap-Gönyủ közötti szakaszának hajózási viszonyait javító beavatkozások vizsgálata (Investigation of interventions for navigation improvment at the Danube channel between Szap and Szob). Technical report. 2004 [In Hungarian].

10. PARKER G. Transport of Gravel and Sediment Mixtures. In M. Garcia (Ed.), Sedimentation Engineering (pp. 165251). American Society of Civil Engineers. 2008.

11. Deltares system. 3D/2D modelling suite for integral water solutions, Delft3D-FLOW, User Manual. Delft: Deltares. 2014.

12. ASHIDA K., MICHIUE M. Study on hydraulic resistance and bedload transport rate in alluvial streams. Transactions of Japan Society of Civil Engineering, 206, 59, 1972.

13. JANSSEN S.R. Testing sediment transport models under partial transport conditions. MSc Thesis, manuscript: University of Twente. 2010.

14. EGIAZAROFF I.V. Calculation of Nonuniform Sediment Concentrations. Journal of the Hydraulics Division, 91 (4), $225, \mathbf{1 9 6 5}$.

15. WU W., WANG S.S.Y., JIA Y. Nonuniform sediment transport in alluvial rivers. Journal of Hydraulic Research, 38 (6), 427, 2000.

16. RECKING A. BedloadWeb User Manual. 2019.

17. PARK S., LEE S., HAN K. Development of technique estimating sediment load in mountain river. MOLIT final report, land transport R\&D report R\&D/B-01. 2013.
18. MEYER-PETER E., MÜLLER R. Formulas for Bed-Load Transport. IAHSR $2^{\text {nd }}$ meeting, Stockholm, Sweden, 7-9 June. 1948.

19. VAN RIJN L.C. Sediment Transport, Part I: Bed Load Transport. Journal of Hydraulic Engineering, 110 (10), 1431, 1984.

20. SHIELDS A. Application of Similarity Principles and Turbulence Research to Bed-Load Movement. Mitt. Preuss. Versuchsanst. Wasserbau Schiffbau, 26 (5-24), 47, 1936.

21. PARKER G. Surface-based bedload transport relation for gravel rivers. Journal of Hydraulic Research, 28 (4), 417, 1990.

22. WILCOCK P.R., CROWE J.C. Surface-based transport model for mixed-size sediment. Journal of Hydraulic Engineering-Asce, 129 (2), 120, 2003.

23. EINSTEIN H.A. The Bed-Load Function for Sediment Transportation in Open Channel Flows. Washington. 1950.

24. WILCOCK P.R., KENWORTHY S.T. A two-fraction model for the transport of sand/gravel mixtures. Water Resources Research, 38 (10), 1, 2002.

25. FISCHER-ANTZE T., RÜTHER N., OLSEN N., GUTKNECHT D. Three-dimensional (3D) modeling of non-uniform sediment transport in a channel bend with unsteady flow. Journal of Hydraulic Research, 47 (5), 670. 2009.

26. TÖRÖK G.T., BARANYA S., RÜTHER N. 3D CFD Modeling of Local Scouring, Bed Armoring and Sediment Deposition. Water, 9 (1), 56, 2017.

27. LAMB M.P., DIETRICH W.E., VENDITTI J.G. Is the critical Shields stress for incipient sediment motion dependent on channel-bed slope ? Journal of Geophysical Research, 113, 1, 2008.

28. BIALIK R.J., CZERNUSZENKO W. On the numerical analysis of bed-load transport of saltating grains. International Journal of Sediment Research, 28 (3), 413. 2013.

29. ZANKE U.C.E. On the influence of turbulence on the initiation of sediment motion. International Journal of Sediment Research, 18 (1), 17, 2003.

30. HABERSACK H., KREISLER A. Sediment Transport Processes. In M. Beniston (Ed.), Dating Torrential Processes on Fans and Cones (pp. 51-74). Springer Dordrecht Heidelberg New York London. 2013.

31. UNAL N.E. Shear Stress-Based Analysis of Sediment Incipient Deposition in Rigid Boundary Open Channels. Water, 10 (10), 1399, 2018.

32. TÖRÖK G.T., BARANYA S., RÜTHER N., SPILLER S. Laboratory analysis of armor layer development in a local scour around a groin. In Proceedings of the International Conference on Fluvial Hydraulics, RIVER FLOW 2014 (pp. 1455-1462). Lausanne: Taylor and Francis Group. 2014.

33. TÖRÖK G.T., BARANYA S., RÜTHER N. River bed armoring in a local scour under no-supply conditions; experimental investigation and numerical model validation. In $18^{\text {th }}$ EGU General Assembly (Vol. 18:172792). Vienna, Austria. 2016

34. REIDAR B., OLSEN N. A Three-Dimensional Numerical Model for Simulation of Sediment Movements in Water Intakes with Moving Option. Trondheim. 2018.

35. OLSEN N.R.B. Numerical Modelling and Hydraulics. Online manuscript. 2012.

36. BIHS H. REEF3D: User Guide. Trondheim. Retrieved from https://reef3d.wordpress.com/ 2019. 
37. FISCHER-ANTZE T., STOESSER T., BATES P., OLSEN N.R.B. 3D numerical modelling of open-channel flow with submerged vegetation 3D numerical modelling of openchannel flow with submerged vegetation Modélisation numérique 3D d ' un écoulement en canal avec vegetation submergée. Journal of Hydraulic Research, 39 (3), 303, 2013.

38. YANG J., NEPF H. Impact of Vegetation on Bed Load Transport Rate and Bedform Characteristics. Water Resources Research, (July). 2019.

39. HÄMMERLING M., WALCZAK N., NOWAK A., MAZUR R., CHMIST J. Modelling Velocity Distributions and River Bed Changes Using Computer Code SSIIM below Sills Stabilizing the Riverbed. Polish Journal of Environmental Studies, 28 (3), 1165, 2019.

40. TÖRÖK G.T., BARANYA S., RÜTHER N. Threedimensional numerical modeling of non-uniform sediment transport and bed armoring process. In $18^{\text {th }}$ Congress of the Asia \& Pacific Division of the International Association for Hydro-Environment Engineering and Research 2012. Jeju. 2012.

41. ĐORĐEVIĆ D. Application of 3D Numerical Models in Confluence Hydrodynamics Modelling, 8. Retrieved from http://cmwr2012.cee.illinois.edu/Papers/Special Sessions/ High-Dimensional Computational Modeling of Rivers and Streams/Dordevic.Dejana.pdf 2012.

42. ESMAEILI T., SUMI T., KANTOUSH S.A., KUBOTA Y., HAUN S., RÜTHER N. Three-Dimensional Numerical Study of Free-Flow Sediment Flushing to Increase the Flushing Efficiency: Water, 9 (11), 2017.

43. BARANYA S., OLSEN N.R.B., STOESSER T., STURM T. Three-dimensional rans modeling of flow around circular piers using nested grids. Engineering Applications of Computational Fluid Mechanics, 6 (4), 648, 2012.

44. TÖRÖK G.T., BARANYA S., RÜTHER N. Validation of a combined sediment transport modelling approach for the morphodynamic simulation of the upper Hungarian Danube River. In $19^{\text {th }}$ EGU General Assembly (Vol. 19:15749). Vienna, Austria. 2017.

45. TÖRÖK G.T., JÓZSA J., BARANYA S. A Shear Reynolds Number-Based Classification Method of the Nonuniform Bed Load Transport. Water, 11 (1)(73), 1, 2019.

46. VAN RIJN L.C. Sediment Transport, Part II: Suspended Load Transport. Journal of Hydraulic Engineering, 110 (11), 1613, 1984

47. TÖRÖK G.T. Methodological improvement of morphodynamic investigation tools for rivers with non-uniform bed material by. PhD Thesis, manuscript: Budapest Univerity of Technology and Economics. Retrieved from http://hdl.handle.net/10890/5505, 2018.

48. BARANYA S. River Bed Material Mapping to Support Habitat Assesment in Large Rivers. In $12^{\text {th }}$ International Symposium on Ecohydraulics. Tokyo, Japan. 2018.

49. FLEIT G., BARANYA S., TÖRÖK G.T. Élöhely szempontú folyószabályozás támogatása korszerü terepi mérésekkel és számítógépes modellezésse (Supporting river regulation for habitat aspect with up-to-date field measurements and numerical modeling). Hidrológiai Közlöny, 95 (5-6), 22, 2015 [In Hungarian].

50. KONDOR G. Hordalékmodellek összehasonlító vizsgálata és alkalmazásuk a Duna morfodinamikai változásainak szimulációjára (Comparative study of sediment transport models and morphodinamic investigation of the Danube by numerical modeling). MSc Thesis, manuscript: Budapest Univerity of Technology and Economics. 2014 [In Hungarian].

51. Dang T.A., Park S.D. Experimental analysis and numerical simulation of bed elevation change in mountain rivers. Springer Plus, 5 (1), 1075, 2016.

52. FICSOR J. Lebegtetett hordalék vizsgálata a Felsőmagyarországi Duna-szakaszon (Study of suspended sediment transport on the upper Hungarian reach of the Danube River). Thesis, manuscript: Budapest University of Technology and Economics. 2016 [In Hungarian].

53. TÖRÖK G.T., BARANYA S. Morphodynamic investigation of the Danube River by a novel sediment transport modelling method. In $20^{\text {th }}$ EGU General Assembly (Vol. 20:15580). Vienna, Austria. 2018.

54. FERNÁNDEZ R., GARCÍA M.H., PARKER G. Upper Mississippi River Flow and Sediment Characteristics and Their Effect on a Harbor Siltation Case. Journal of Hydraulic Engineering, 144 (10), 1, 2018.

55. BME-VVT O.V.F., VIZITERV-Environ Kft. A mértékadó árvízszintek országos felülvizsgálata (Reconsideration of the high water levels in Hungary). Budapest, Hungary. 2014 [In Hungarian].

56. LIEDERMANN M., GMEINER P., KREISLER A., TRITTHART M., HABERSACK H. Insights into bedload transport processes of a large regulated gravel-bed river. Earth Surface Processes and Landforms. 2017.

57. CSITI B. A Duna múltbeli lebegtetett hordalékadatainak módszertani elemzése (Methological analysis of the former suspended sediments in Danube River). BSc Thesis, manuscript: Budapest Univerity of Technology and Economics, BSc Thesis. 2017 [In Hungarian].

58. GLOCK K., TRITTHART M., HABERSACK H., HAUER C. Comparison of Hydrodynamics Simulated by 1D, 2D and 3D Models Focusing on Bed Shear Stresses. Water, 11 (2), 30, 2019.

59. CHENG Z., LEE K., KIM D., MUSTE M., VIDMAR P., HULME J. Experimental Evidence on the Performance of Rating Curves for Continuous Discharge Estimation in Complex Flow Situations Experimental evidence on the performance of rating curves for continuous discharge estimation in complex $\mathrm{fl}$ ow situations. Journal of Hydrology, 568 (November), 959, 2018.

60. ZHU Q., PROOIJEN B.C. VAN, WANG Z.B., MA Y.X., YANG S.L. Bed shear stress estimation on an open intertidal flat using in situ measurements. Estuarine, Coastal and Shelf Science, 182, 190, 2016.

61. HUAN L.I.U., JIA-XUE W.U. Estimation of Bed Shear Stresses in the Pearl River Estuary. China Ocean Engineering, 29 (1), 133, 2015.

62. BARANYA S., JÓZSA J., TÖRÖK G.T., RÜTHER N. A comprehensive field analysis of a river confluence. In River Flow 2012 - Proceedings of the International Conference on Fluvial Hydraulics 1, 2012.

63. SZILO J., BIALIK R.J. Bedload transport in two creeks at the ice-free area of the Baranowski Glacier, King George Island, West Antarctica. Polish Polar Research, 38 (1), 21, 2017.

64. SZIŁO J., BIALIK R.J. Grain Size Distribution of Bedload Transport in a Glaciated Catchment (Baranowski Glacier, King George Island, Western Antarctica). Water, 10 (4), 360, 2018. 
